\title{
Demand on Non-Medical Health Professions Training: Adaptation to New Challenges of the Aging Populations (letter)
}

M. Hardy (Maria Hardy)1,3, P. Vansac (Peter Vansac)33, J. Benca (Juraj Benca)2, M. Palun (Miroslav Palun)², A. Gallova (Andrea Gallova) ${ }^{3}$, M. Susta (Marek Susta)?, J. Otrubova (Jana Otrubova)', M. Jankechova (Monika Jankechova)', L. Matulnikova (Ludmila Matulnikova)2, S. Subramanian (Selvaraj Subramanian)', M. Sramkova (Maria Sramkova)2,4, P. Cmorej (Patrik Cmorej) ${ }^{4}$, D. West (Daniel West) ${ }^{4}$, D. Kimuli

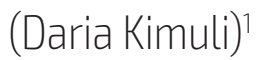

${ }^{1}$ Public Health MSC and PhD Program of SEU, Kuala Lumpur, MY

\section{Original Article}

2 SEUC Health program, St. Lesley College Nove Zamky, SK

${ }^{3}$ St. John Neumann Institute, Pribram, CZ

${ }^{4}$ University of Scranton, Panuska School of Professional Studies, PA, USA

\section{E-mail address:}

pechacova.daria@gmail.com

\section{Reprint address:}

Daria Kimuli

South B Mukuru 1090

Nairobi, KE

Source: Clinical Social Work and Health Intervention

Pages: $74-75$

Volume: 9

Cited references: 2

Issue: 3

\section{Reviewers:}

Peter Marks - marks.peter@hotmail.com

\section{Key words:}

Health Professionals.

\section{Publisher:}

International Society of Applied Preventive Medicine i-gap

CSWHI 2018; 9(3): 74 - 75; DOI 10.22359/cswhi_9_3_11 @ 2018 Clinical Social Work and Health Intervention

\section{Abstract:}

This current letter to the editor reflects on a series of papers published in Clinical Social Work Journal (1-3) or refugees and migrants health 
care during the new 2015 - 2018 crisis: The unpreparedness of most non-Doctor Health Care Workers solve health and social problems migrants and refugees due to the lack of language and education in migrant/refugee health and related topics. The Majority of V4 + Austria countries deal with but very few also teach socio-legal problems of children and mothers, reunifications of families, humanitarian deals, tropical diseases and other subjects which appeared from the praxis during these four years of migrant crisis in Greece/Italy, where 1.5million per year of immigrants and refugees escaped via Balkan or Mediterranean Route and potential V4 - citizens.

With the increasing proportion of elderly population, the need for Health Care Professionals is increasing as well. An International Conference in May 2018 was held in Bratislava to facilitate the East-West exchange and promotion of non-Medical Health Sciences and outcome of Health Care students. Serial discussions about e.g. Podiatric or Community Health are not included in the studies of university students in Central Europe at all. Despite the fact, that the critically ill population is rising, both in community and in long term facilities, making this problem emerging.

\section{References}

1. HERDICS G (2017) Editorial in Marginalized Populations. Clin Soc Work.9.2017.3.23

2. BUCKO L (2016) Editorial Acta Missiologica,6.2016.2.2-4

Table 1: Missing programs for HCW causing gaps in education

\begin{tabular}{|l|c|c|c|c|}
\hline \multicolumn{1}{|c|}{$\begin{array}{c}\text { Name of the teaching } \\
\text { program for HCW }\end{array}$} & AT, DE, IT, FR, BE, NE & $\begin{array}{c}\text { EU-V4 } \\
\text { SK, PL, CR, HU }\end{array}$ & USA & WP Asia \\
\hline Nursing & yes & yes & yes & yes \\
\hline Physiotherapy & yes & yes & yes & yes \\
\hline Medical Technology & yes & yes & yes & yes \\
\hline Dental Technics & no & yes & yes & no \\
\hline Podiatrics & no & no & yes & no \\
\hline Public Health & yes & no & yes & yes \\
\hline Community Health & no & yes & yes & no \\
\hline Tropical Health & no & yes & yes & no \\
\hline Radiology & yes & yes & yes & no \\
\hline Rescue/medicallst aid & yes & & & \\
\hline
\end{tabular}

